\title{
The Increasing Importance of the European Convention on Human Rights in the Tax Area
}

\author{
Delphine de Drouâs and Isabelle Sienko, Coopers \& Lybrand CLC Juridique et Fiscal, Paris
}

In a case dated 29 April 1997, the French supreme civil court (Cour de Cassation), which deals mainly with litigation regarding registration duties and wealth tax, sanctioned the system of tax penalties in France. The court criticized such system which does not accept any moderation when determining the seriousness of the offences committed. The automatic enforcement of a fine of 200 per cent (now 80 per cent) for failure to pay car tax was at issue in this case.

Tax penalties are governed by French legislation: depending on the nature of the offence (failure to declare, insufficient declaration, etc.) and its seriousness (bad faith, fraudulent practices, abuse of law), a set increase (most often 40 per cent or 80 per cent) can be applied in addition to late interest $(9$ per cent per year). The role of the tax administration, and until now the judge, has been restricted to evaluating whether the conditions set forth in the statutes and regulations are met. If they are, the penalty is automatically applied and cannot be reduced (for example from 40 per cent to 20 per cent) to take attenuating circumstances into account.

The French tax authorities try to limit the scope of the Cour de Cassation decision which could trigger an overall questioning of the entire system of tax penalties in France. Presently, their tendency is to interpret this case restrictively and to refuse to widen its scope to include other tax penalties.

This innovative case law is founded on Art. 6 of the European Convention on Human Rights which guarantees the right for any person to a fair trial in criminal matters. According to the European Court of Human Rights, tax increases which are not intended to compensate for a loss suffered by the Treasury (EJHR, 24 February 1994, Bendenoun case), qualify as being of a criminal nature. The Cour de Cassation therefore requires this right to be respected with regard to 'any system of tax increase'.

The French supreme tax court (Conseil d'Etat), which deals with litigation regarding direct taxation and VAT, considered that tax penalties were 'criminal charges' according to the terms of Art. 6 of the abovementioned treaty (Conseil d'Etat, 31 March 1995, Méric case) but until now has refused to recognize the authority of the administrative judge to attenuate the tax penalties according to the seriousness of the offence committed (Conseil d'Etat, Opinion of 5 April 1996, Houdmond case). Thus, the guarantees set forth by the treaty are being violated if an administrative court cannot be adequately petitioned to judge the fairness and appropriateness of sanctions applied.

The somewhat conservative position of the Conseil d'Etat can be explained by the fact that the supreme court wants to avoid, where possible, any solution that would challenge national law.

It will be difficult for the Conseil d'Etat to maintain a position in conflict with the case law of the Cour de Cassation as well as that of the European Court of Human Rights.

As a matter of fact, an overall favourable trend towards a closer appropriateness of penalties to the specific circumstances of each case is noted with, for instance, a decision of the Paris administrative court dated 22 April 1997, which rejected the application of an 80 per cent penalty for abuse of law. The grounds were that there was no proof that the wrong was intentional.

Sooner or later the Conseil d'Etat will have to follow this trend, which could even be extended to late interest penalties. Such penalties are due to compensate for a loss suffered by the French Treasury because of late collection of the money owed to it. They have not yet been qualified as being of a 'criminal' nature, but due to the high rate $(9$ per cent per year), some of such penalties could be qualified as such in the future.

In future it is also probable that the system of tax penalties will be reviewed: the sanction applied should be moderated depending on the circumstances of the case. When it does, thanks to the European Convention on Human Rights, it will represent a mini tax revolution. 